\title{
EKSPLORASI MIXED-PROGRAM (PASAR BUNGA, KULINER, DAN TAMAN KOTA) DALAM MERANCANG 3 FLORE KEBAYORAN LAMA, JAKARTA SELATAN
}

\author{
Febriana $^{1)}$, Suryono Herlambang ${ }^{2)}$ \\ 1)Program Studi S1 Arsitektur, Fakultas Teknik, Universitas Tarumanagara, sie.febriana@gmail.com \\ 2)Program Studi S1 PWK, Fakultas Teknik, Universitas Tarumanagara, suryonoh@ft.untar.ac.id
}

\begin{abstract}
Abstrak
Third Place merupakan tempat publik yang informal untuk bersosialisasi. Salah satunya adalah Ruang Terbuka Hijau (RTH). RTH merupakan sebuah kebutuhan dasar yang dibutuhkan masyarakat perkotaan. RTH paling besar DKI Jakarta berada di kota Jakarta Selatan, kecamatan Kebayoran Lama, kelurahan Kebayoran Lama Utara. Tetapi, setelah dianalisa RTH paling besar persentasenya untuk pemakaman. Padahal, target untuk mencapai tingkat RTH minimal kota masih jauh. Selain itu, terjadi perbedaan kontras antara kawasan menengah ke atas dan menengah ke bawah sehingga terlihat tidak setara karena adanya standar sosial tertentu. Oleh karena itu, proyek Third Place yang berada di Jalan Raya Kebayoran Lama ini menggunakan tema "Urban Park" untuk menghidupkan kembali RTH. Proyek ini ingin menunjukkan dan menyatukan perbedaan sosial, serta permasalahan RTH dari isu yang dihadapi sehingga keberagaman tersebut dapat diterima dan diterapkan sehingga masyarakat lebih berekspresif. Perbedaan yang dihadapi ini dianalogikan seperti buket bunga, dengan menjadikan projek ini "Main Attractor", menghubungkan stasiun Kebayoran Lama, kawasan menengah ke atas, Gandaria City, pemakaman Tanah Kusir, dan kawasan menengah ke bawah untuk mencerminkan kawasan Kebayoran Lama Utara dengan menghadirkan tiga program utama untuk mewujudkan visi, yaitu: pasar bunga, kuliner, dan taman yang menggunakan sistem lahan sewa setiap akhir pekan yang dapat dilakukan bersama keluarga ataupun teman di rooftop garden, serta membuat acara berkebun sesuai dengan musim bunga yang bermekaran pada waktu tertentu. Tujuan dari proyek ini agar sebagai sarana hiburan masyarakat dari rutinitas kota; merasakan pengalaman berada di taman di tengah kota; serta sebagai tempat pertemuan dan berkumpul masyarakat.
\end{abstract}

Kata kunci: bunga; kuliner; pasar; perkotaan; taman

\begin{abstract}
Third Place is an informal public place to socialize, example: Green Open Space which is a mandatory demand for an urban society. The largest green open space on DKI Jakarta located in the South Jakarta, sub-district of Kebayoran Lama, North Kebayoran Lama. However, after analyzing the largest percentage for cemeteries. So, the target to reach minimum green open space level for the city is still far away. There is a difference in contrast between upper intermediate district and lower intermediate district proves social standards were never been equal. Therefore the "Third Place" on Jalan Raya Kebayoran Lama leads "Urban Park" as the theme to ressurrect proper green space. This project want to exhibit the variety of social-class, solve the green open space issues, and make the diversity being accepted. This diversity being interpreted as a flowers bouquet, by pointing this project as a "Main Atrractor" which linked the Kebayoran Lama Station, upper intermediate district, Gandaria City, Tanah Kusir cemetery and the lower intermediate district that reflects North Kebayoran Lama. There are three main program as the vision to-offer which: flower market, culinary, and urban park with the rental land system every weekend with family or friends on the rooftop garden, as well as making a gardening event in accordance with the blooming flower season at a certain time. The intention of this project is to be public entertainment from the the city routines; along with an experience on urban park in the main of the city; including a convocation area and community.
\end{abstract}

Keywords: culinary; flower; market; park; urban 


\section{PENDAHULUAN}

\section{Latar Belakang}

DKI Jakarta merupakan salah satu kota metropolitan di Indonesia, sehingga perlu menyediakan wadah segala aktivitas untuk masyarakatnya. Kondisi ini didukung dengan beragam infrastruktur yang telah tersedia ataupun dalam masa pembangunan. Tetapi, masyarakat perkotaan sebagai makhluk sosial tetap membutuhkan ruang publik informal untuk bersosialisai. Oleh karena itu, third place (ruang ketiga) diharapkan sebagai tempat relaksasi atau beristirahat dari rutinitas kota. Menurut CNN Indonesia (2019), pada tahun 1985 Ruang Terbuka Hijau (RTH) yang ada di Jakarta mencapai $25,85 \% .{ }^{1}$ Dua puluh lima tahun kemudian, jumlahnya menurun drastis menjadi 9\%. Pada tahun 2019, WRI (World Resource Indonesia) mengatakan RTH yang ada di Jakarta baru sekitar $14,9 \%$. Hal ini sudah mengalami peningkatan dibandingkan dengan tahun-tahun sebelumnya. Padahal dalam UU RI nomor 26 tahun 2007 tentang Penataan Ruang telah mengamanatkan bahwa jumlah RTH kota seharusnya minimal menjadi $30 \%$ dari luas wilayah kota tersebut. ${ }^{2}$

Luas RTH terus menurun sejak hadirnya bangunan gedung pencakar langit dan pusat perbelanjaan. Dalam kurun waktu dua dekade terakhir, frekuensi kemunculan permukiman liar di sejumlah wilayah yang sebenarnya tidak diperuntukan untuk lahan hunian semakin tinggi. Maka dari itu, Bapak Gubernur DKI Jakarta Anies Baswedan mengusulkan ingin bekerja sama dengan semua pihak baik pemerintah pusat maupun pihak swasta. Terutama dengan mendorong adanya keterlibatan pihak swasta yang harus melakukan, mengadakan, menyediakan RTH sebanyak $10 \%$. Hal ini bisa dilakukan dengan membangun ruang hijau seperti: pembuatan green garden, vertical garden, roof garden, ataupun konsep-konsep RTH lainnya. Kebayoran Lama Utara merupakan sebuah kawasan yang memiliki potensi yang kuat dengan berbagai isu yang kompleks. Kawasan ini menjadi salah satu penyumbang RTH terbesar di Jakarta Selatan. Tetapi, masyarakat di sekitar tidak pernah merasa jika menyediakan ruang publik atau tempat wisata sebagai tempat relaksasi, berkumpul, dan bermain bersama. Masyarakat sekitar cenderung pergi ke mall ataupun lapangan olahraga di kelurahan tetangga. Padahal, RTH merupakan sebuah kebutuhan dasar masyarakat perkotaan.

\section{Rumusan Permasalahan}

Rumusan masalah dari penelitian yang dapat diperoleh dalam laporan ini berdasarkan latar belakang yang telah dijelaskan diatas, sebagai berikut:

a. Mampu menjawab permiabilitas dan keterbukaan yang dibutuhkan ruang ketiga.

b. Menunjang target RTH minimal kota masih sangat jauh.

c. Mengeksplorasi program yang dapat menyatukan perbedaan sosial yang kontras dengan menyesuaikan aktivitas masyarakat dan potensi kawasan.

\section{Tujuan}

Tujuan dari proyek ini, sebagai berikut:

a. Menyelesaikan permiabilitas dan keterbukaan yang dibutuhkan ruang ketiga.

b. Meningkat RTH minimal kota untuk mencapai target.

c. Menghadirkan program yang dapat mencerminkan kawasan, menunjukan dan menyatukan perbedaan sosial agar dapat diterima masyarakat sehingga lebih berekspresif.

\footnotetext{
${ }^{1}$ CNN Indonesia. "Target Masih Jauh DKI Ingin Swasta Sumbang 10 Persen RTH" https://www.cnnindonesia.com/nasional/20191017195256-20-440515/target-masih-jauh-dki-ingin-swastasumbang-10-persen-rth. (Diakses pada 15 Februari 2020, 20:00)

2 Kemenkeu.go.id. "Undang-Undang Republikl nomor 26 tahun 2007" https://idih.kemenkeu.go.id/fullText/2007/26TAHUN2007UU.HTM (Diakses pada 15 Februari 2020, 19:45)
} 


\section{KAJIAN LITERATUR}

\section{Third Place (Ruang Ketiga)}

Menurut Ray Oldenburg (The Problem of Place in America), istilah third place adalah tempattempat publik yang diadakan secara tetap, sukarela, informal untuk kegiatan informal, seperti berkumpul bersama. ${ }^{3}$ Third place (tempat ketiga) adalah tempat netral dan informal untuk mengobati stress, kesepian, dan kebosanan. Biasanya terletak diantara tempat tinggal (first place) dan tempat kerja (second place). Aksesibilitas sangat penting karena menjadi permiabilitas masyarakat. Menurut Ray Oldenberg, kriteria third place, ${ }^{4}$ sebagai berikut:

a. Neutral (netral): netral bagi siapa saja dengan mudah diakses.

b. Level (sejajar): tempat yang inklusif tanpa adanya perbedaan status.

c. Conversation (percakapan): percakapan merupakan elemen paling penting.

d. Accessible (aksesibilitas): memberikan dan memenuhi kebutuhan masyarakatnya.

e. Regular (pengunjung tetap): memiliki pengunjung tetap baik masyarakat setempat maupun bukan.

f. A Low Profile (sederhana): tidak mahal dan sederhana.

g. Playful (menyenangkan): memiliki sifat yang menyenangkan.

h. A Home Away from Home (jauh dari rumah)

\section{Public Space (Ruang Publik)}

Public space adalah ruang dimana semua orang memiliki hak yang sama untuk mengakses atau mengadakan kepetingan atau kegiatan publik, tanpa ada batasan ruang dan waktu. ${ }^{5} \mathrm{Di}$ tempat ini, tidak memandang jenis kelamin, ras, etnik, umur, agama, budaya, kondisi ekonomi ataupun sosial. Menurut hukum Town and Country Planning Act (1990), ${ }^{6}$ public space terbagi menjadi beberapa, yaitu:

a. Public open space (ruang terbuka publik): digunakan oleh beberapa otoritas lokal yang diakses publik tanpa fasilitas formal untuk ketentuan rekreasi

b. Public space (ruang publik): jalan, trotoar, alun-alun, pinggir laut dan kawasan pejalan kaki, pasar, tempat perbelanjaan, dan pengerasan

c. Public green space (ruang terbuka hijau): taman kota, kebun, taman pedesaan, kanal, dan tepi sungai

d. Public outdoor sport facilities (fasilitas publik olahraga luar): lapangan bermain yang biasanya ditemukan didalam taman atau berdekatan dengan taman

e. Playscape (ruang bermain): taman bermain anak-anak atau tempat bermain skate yang bisa ditemukan didalam taman atau berdiri sendiri

\section{Urban Space (Ruang Kota)}

Ruang kota pada dasarnya dibedakan oleh suatu karakteristik yang menonjol, seperti kualitas pengolahan detail dan aktivitas yang berlangsung didalmnya. Ruang kota yang ideal dilingkupi oleh dinding, lantai dan mempunyai maksud yang tegas untuk melayani. Sekelompok bangunan baik perkantoran maupun komersial dapat membentuk ruang disekelilingnya baik berupa: plaza, jalan maupun ruang terbuka lainnya. Dalam hal ini, tempat tertentu dalam kota berfungsi sebagai lokasi suatu aktivitas penting. Tetapi, tidak mempunyai pelingkup fisik dan lantai yang semestinya. ${ }^{7}$

\footnotetext{
${ }^{3}$ Michael Larice dan Elizabeth Macdonald. The Urban Design Reader: Two Views of Outside in British City Centres, Issue 108 [New York: Routledge, 2nd ed, 2007] hal. 24-27.

${ }^{4}$ Ray Oldenburg. The Great Good Place: Cafes, Coffee Shops, Bookstores, Bars, Hair Salons, and Other Hangouts at The Heart of Community, [London: Da Capo Press, 1999 ed] hal. 22-42.

${ }^{5}$ Iftitach. "Public Space" https://id.scribd.com/doc/172700187/Public-Space [Diakses 15 Februari 2020 22.00]

${ }^{6}$ London Assembly. Public Life in Private Hands: Managing London's Public Space, [Greater London Authority: 2011] hal. 47.

${ }^{7}$ Eko Budihardjo dan Djoko Sujarto. Kota Berkelanjutan (Sustainable City). [Alumni: 1999] hal. 63.
} 


\section{Public Green Space (Ruang Terbuka Hijau)}

Ruang Terbuka Hijau adalah area yang memanjang/jalur atau mengelompok, yang penggunaannya lebih bersifat terbuka, tempat tumbuh tanaman, baik secara alamiah maupun yang sengaja ditanam. Penyediaan dan pemanfaatan RTH dalam RTRW Kota/RDTR kota/RTR Kawasan Strategis Kota/ RTR Kawasan Perkotaan, dimaksudkan untuk menjamin tersedianya ruang yang cukup, ${ }^{8}$ antara lain:

a. Kawasan konservasi untuk kelestarian hidrologis

b. Kawasan pengendalian air larian dengan menyediakan kolam retensi

c. Area pengembangan keanekaragaman hayati

d. Area penciptaan iklim mikro dan pereduksi polutan di kawasan perkotaan

e. Tempat rekreasi dan olahraga masyarakat

f. Tempat pemakaman umum

g. Pembatas perkembangan kota ke arah yang tidak diharapkan

h. Pengamanan sumber daya baik alam, buatan maupun historis

i. Penyediaan RTH yang bersifat privat, melalui pembatasan kepadatan serta kriteria pemanfaatannya

j. Area mitigasi/evakuasi bencana

k. Ruang penempatan (signage) sesuai dengan peraturan perundangan dan tidak mengganggu fungsi utama RTH tersebut

Data RTH Kebayoran Lama 70\% digunakan sebagai pemakaman, 9\% berada di kelurahan Kebayoran Lama Utara, serta 21\% tersebar di kelurahan lainnya: Grogol Utara, Grogol Selatan, Cipulir, Kebayoran Lama Selatan, dan Pondok Pinang. ${ }^{9}$

\section{Urban Park (Taman Kota)}

Area terbuka dari RTH yang hadir dalam konteks perkotaan atau pinggirannya dengan fungsi rekreasi untuk kualitas hidup yang lebih baik. Taman kota dapat melayani kebutuhan dan fungsi yang berbeda (istirahat, bermain, kegiatan olahraga, fasilitas, pusat budaya dan rekreasi). ${ }^{10}$ Selain itu, dapat memberikan kontribusi penting bagi mitigasi iklim perkotaan sehingga mengurangi polusi dan panas.

Dalam mendesain sebuah taman kota, harus mempertimbangkan aspek, seperti:

a. Tempat bermain anak: dapat digunakan berbagai kalangan umur untuk mendorong aktivitas fisik yang inklusif

b. Dapat mendidik atau melatih warga: dengan mempelajari karakteristik alami daerah tersebut seperti: vegetasi, fauna, sejarah, dan budaya

c. Kegiatan untuk kesehatan fisik dan mental untuk rekreasi dan agregasi

d. Makhluk lain: binatang, tumbuhan

e. Bangku atau area duduk: sebagai tempat penting untuk interaksi sosial, membaca, beristirahat.

f. Jalur pedestrian: harus mudah di akses semua kalangan.

g. Akses difabel

Elemen proyek diperlukan dalam mendesain dengan tujuan memberikan identitas yang unik, empati, utilitas dan RTH. Ada beberapa elemen yang perlu dipertimbangkan, yaitu:

\footnotetext{
8 Library Binus. "Bab II: Landasan Teori"

http://library.binus.ac.id/eColls/eThesisdoc/Bab2/RS1 20171326 Bab2.pdf [Diakses 15 Februari 2020, 21.30] hal. 1.

9 Jakarta Open Data. "Data Rekap Luas Ruang Terbuka Hijau Per Kotamadya di DKI Jakarta"

https://data.jakarta.go.id/dataset/rekapluasruangterbukahijauperkotamadyadidkijakarta [Diakses 15 Februari 2020, 21.00]

${ }^{10}$ Biblus. "Urban Park Design and Planning: Main Types and Features of Green Areas Together with a 3D Model Ready to Use" http://biblus.accasoftware.com/en/urban-park-design-concepts-and-key-elements/ [Diakses 15 Februari 2020, 20.30]
} 
a. Tanah: variasi topografi, bukit, parit, atau anak tangga dapat memberikan persepsi dan dimensi berbeda.

b. Vegetasi: variasi kromatik yang terlihat digunakan untuk berbagai kombinasi warna tanaman, menggunakan prinsip kromoterapi, atau tanaman musiman

c. Air mengalir atau tergenang: terlepas dari aspek estetika dan emosional, bisa sebagai mitigasi, penyegaran dan pelembab, meningkatkan jumlah vegetasi dan utilitas untuk pengguna taman.

d. Bayangan: dengan menggunakan berbagai variasi cahaya baik alami atau buatan sesuai dengan tujuan desain yang ingin dicapai.

\section{Urban Park as Third Place}

Urban park dipilih sebagai third place dalam proyek ini diharapkan sebagai sarana hiburan masyarakat dari rutinitas kota dengan memberikan pengalaman merasakan taman di tengah kota. Selain itu, untuk menunjang minimal kebutuhan kota yang masih sangat jauh, serta menjadi wadah berkumpul masyarakat setempat. Urban park ini menggunakan sistem lahan sewa "julmanongjang" sebagai tempat komersil. Jumalnongjang adalah salah satu ide kreatif dari orang Korea. Jumalnongjang berasal dari bahasa Korea yang berarti "pertanian akhir pekan". ${ }^{11}$ Orang Korea merindukan kehidupan mereka di pedesaan karena sudah bosan dengan kehidupan perkotaan. Dengan latar belakang warga perkotaan bercocok tanam di halaman rumah walaupun kecil-kecilan. Tetapi, mengingat terbatasnya lahan yang mereka punya dengan harga tanah yang sangat mahal. Maka, jumalnongjang ini menggunakan sistem sewa tanah sebagai pertanian.

\section{Bunga}

Menurut Wikipedia, Bunga atau kembang (bahasa Latin: flos) adalah alat reproduksi seksual pada tumbuhan berbunga (divisio Magnoliophyta atau Angiospermae, tumbuhan berbiji tertutup). ${ }^{12}$ Pada bunga terdapat organ reproduksi, yaitu benang sari dan putik. Bunga dapat muncul secara tunggal maupun banyak dalam satu rangkaian. Bunga yang muncul secara banyak disebut sebagai bunga majemuk atau inflorescence. Pada beberapa spesies, bunga majemuk dapat dianggap awam sebagai bunga (tunggal), misalnya pada Anthurium dan bunga matahari. Satuan bunga yang menyusun bunga majemuk disebut floret.

Merangkai bunga adalah seni mengatur elemen desain bahan tanaman dan komponen lainnya sesuai dengan prinsip artistik untuk mencapai keindahan, harmoni, perbedaan, dan ekspresi. ${ }^{13}$ Ketentuannya susunan bunga, desain atau komposisi adalah identik. Komponen yang digunakan dalam membuat desain adalah bahan tanaman, wadah, latar belakang, dan mekanik. Komponen opsional yang dapat ditambahkan ke desain termasuk aksesoris, objek unggulan, dan pangkalan.

Dalam merangkai bunga, terdapat beberapa prinsip desain dasar yang digunakan, yaitu:

a. Keseimbangan: stabilitas visual yang dicapai dengan menempatkan bobot visual atau aktual yang sama pada sisi yang berlawanan sumbu pusat imajiner.

b. Symmetrical (simetris): penempatan elemen dengan jumlah yang sama dari sumbu pusat.

c. Asymmectrical (tidak simetris): penempatan perkiraan berat visual yang sama dari elemen yang berbeda dari sumbu pusat.

d. Dominasi: penguasaan suatu elemen desain oleh satu atau lebih untuk menyiratkan adanya elemen primer dan sekunder dalam desain.

e. Kontras: terdapat elemen yang berlawanan atau tidak sama untuk menekankan perbedaan dan menambah minat.

f. Ritme: jalur visual yang dominan melalui suatu desain dengan menggunakan gradasi dan pengulangan dalam arah linier.

g. Proporsi: hubungan antara satu bidang desain bunga dengan bidang desain lainnya dan untuk desain secara keseluruhan. 
h. Skala: hubungan ukuran masing-masing bagian komponen dari satu desain dan lainnya serta ukuran penataan dengan daerah sekitarnya.

Elemen desain merupakan suatu kualitas visual yang digunakan dalam menciptakan desain dan digunakan untuk semua bentuk seni. Prinsip elemen desain secara efektif, yaitu:

a. Cahaya: penerangan (alami atau buatan) diperlukan untuk penglihatan untuk mempengaruhi warna, bayangan, dan visibilitas suatu desain.

b. Ruang: memerlukan pengaturan dan penempatan desain.

c. Garis: jalur visual yang mengarahkan mata melalui desain dan membentuk struktur kerangka kerja desain dengan membawa ritme sampai ke desain.

d. Bentuk: kontur dua dan tiga dimensi komponen individual maupun desain keseluruhan.

e. Ukuran: dimensi visual garis, bentuk, bentuk, dan ruang.

f. Pola: kualitas visual yang diciptakan oleh kombinasi garis, bentuk, warna, tekstur dan spasi.

g. Tekstur: kualitas permukaan visual, contoh: kasar dan halus, kusam dan mengkilap.

h. Warna: respons visual mata terhadap gelombang cahaya dengan menggunakan antara prinsip-prinsip desain dan warna, seperti: warna hangat (kuning, merah, oranye) terlihat bergerak meneruskan sedangkan warna dingin (biru, hijau, ungu) terlihat semakin jauh. Area warna dingin akan tampak lebih kecil dengan warna hangat meskipun di tempat yang sama. Oleh karena itu, perlu diperhatikan kualitas warna, seperti Hue atau Chroma: nama spesifik warna seperti merah, hijau, dll; Value: nilai warna terang atau gelapnya suatu warna; Intensitas: terang atau buram suatu warna.

\section{Pasar}

Dalam buku Pengantar Bisnis (M Fuad, 2006), pasar adalah satu dari berbagai sistem, institusi, prosedur, hubungan sosial, dan infrastruktur di mana usaha menjual barang, jasa, dan tenaga kerja untuk orang-orang dengan imbalan uang. ${ }^{14}$ Barang dan jasa yang dijual menggunakan pembayaran yang sah, yaitu uang. Pasar memiliki beberapa fungsi lainnya yaitu:

a. Segi ekonomi: tempat transaksi antara produsen dan konsumen (demand dan supply)

b. Segi sosial budaya: kontak sosial secara langsung yang menjadi tradisi suatu masyarakat yang merupakan interaksi antara komunitas pada sektor informal dan formal

c. Segi arsitektur: adanya ciri khas daerah, yang menampilkan bentuk fisik dan artefak.

\section{Kuliner}

Kuliner atau culinary dalam Bahasa Inggris yang berarti berhubungan dengan masak-memasak atau aktivitas memasak. ${ }^{15}$ Kuliner secara umum adalah kegiatan yang berhubungan dengan memasak yang berkaitan erat dengan konsumsi makanan sehari-hari. Dalam perkembangannya, digunakan untuk berbagai macam kegiatan maupun seni kuliner, seperti: seni persiapan, memasak dan penyajian makanan, biasanya dalam bentuk makanan. Wisata kuliner merupakan perpaduan menikmati suatu makanan sambil menikmati suasana, bersantai, sehingga memanfaatkan waktu ke tempat yang menyediakan makanan khas.

\footnotetext{
${ }^{11}$ Syasya. "Julmanongjang Hobi Orang Kota di Korea" https://www.kompasiana.com/lakeisha/5dad5050c0cfa1022f731652/jumalnongjang-hobi-orang-kota-di-korea [Diakses 15 Februari 2020, 19.30]

${ }^{12}$ Virginia GC. "Principles and Elements of Design" http://www.gcvirginia.org/userfiles/file/principleselements.pdf [Diakses 15 Februari 2020, 19.30] hal. 1-2.

${ }^{13}$ Wikipedia. "Bunga” https://id.wikipedia.org/wiki/Bunga [Diakses 15 Februari 2020, 19.00]

${ }^{14}$ Gischa Serafica. "Pasar: Pengertian, Fungsi, Ciri-ciri dan Jenisnya" https://www.kompas.com/skola/read/2020/01/27/120000769/pasar-pengertian-fungsi-ciri-ciri-danjenisnya?page=all\#: :text=Pengertian (Diakses 15 Februari 2020, 21.00)

${ }^{15}$ Kanal Informasi. "Pengertian Kuliner" https://www.kanalinfo.web.id/pengertian-kuliner (Diakses 15 Februari 2020, 20.15)
} 


\section{METODE}

Metode yang digunakan penulis dalam perancangan, sebagai berikut:

a. Metode penelitian kualitatif, ditujukan untuk menginvestigasi tapak dan kawasan tersebut melalui mencari informasi melalui jurnal, buku, maupun internet; melakukan survey ke tempat yang bersangkutan untuk mengamati aktivitas dan perilaku masyarakatnya; serta mengumpulkan beberapa studi literatur, studi kasus, dan informasi sehingga dapat di riset.

b. Metode perancangan analogi, ditujukan dalam tahap perancangan dengan menggunakan analogi buket bunga dengan rekombinasi program terpilih. Perancangan menggunakan konsep "main attractor" dan tema "urban park" yang telah ditentukan setelah dianalisa dan dituangkan ke dalam desain baik dalam proses pembentukan massing type dan unit type. Semua perwujudan desain dituangkan dalam bentuk tulisan, diagram arsitektural, dan gambar kerja. Hal ini untuk menyelesaikan atau menjawab permasalahan yang dihadapi.

\section{DISKUSI DAN HASIL}

\section{Analisis Kawasan}

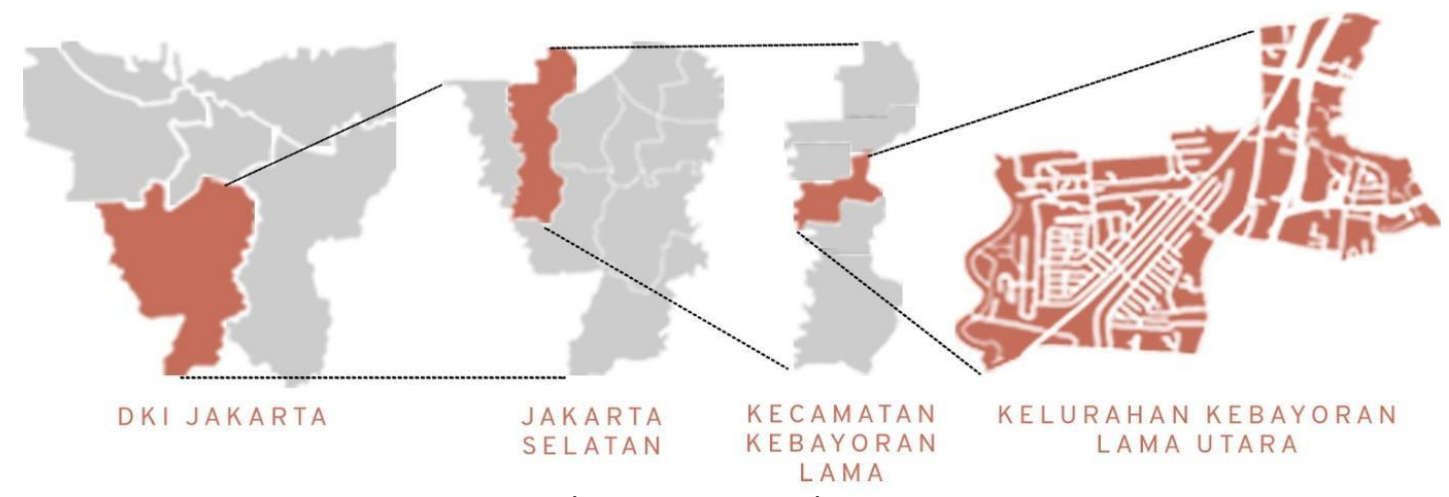

Gambar 1: Peta Letak Kawasan

Sumber: Penulis, 2020

Kelurahan Kebayoran Lama Utara memiliki luas wilayah 178,22 ha dengan sebagian besar wilayahnya permukiman penduduk. Peruntukan tanah digunakan sebesar $80 \%$ perumahan dan perkarangan, $10 \%$ perkantoran/industri, $5 \%$ fasilitas umum, dan $5 \%$ peruntukan lainnya. Mayoritas penduduk beragama Islam bekerja pada sektor perdagangan sebagai pegawai swasta dan sisanya pada sektor jasa. ${ }^{16}$ Kelurahan Kebayoran Lama Utara merupakan salah satu kelurahan dari sepuluh Kelurahan di Kecamatan Kebayoran Lama termasuk dalam Wilayah kota Administrasi Jakarta Selatan. Berdasarkan Keputusan Gubernur KDKI Jakarta Nomor: 1227 tahun 1989, wilayah Kelurahan Kebayoran Lama Utara berbatasan dengan:

a. Utara: Jl. Kramat (Kelurahan Grogol Selatan), Jl. Kebayoran Lama (Kelurahan Cipulir

b. Timur: Kali Grogol (Kelurahan Kramat Pela), Jl. Ciputat Raya (Kelurahan Kebayoran Lama Selatan)

c. Selatan: Jl. Bintaro Raya, Jl. Bungur (Kelurahan Kebayoran Lama Selatan)

d. Barat: Kali Pesanggrahan (Kelurahan Ulujami), Jl. Kebayoran Lama (Kelurahan Cipulir). Hasil analisis Kelurahan Kebayoran Lama Utara terhadap berbagai aspek, yaitu:

a. Urban Form: type box (dominan), rectangle I, U, L, dan T.

b. Figure-ground: perbandingan solid void yang tidak seimbang, dimana kawasan menengah ke bawah padat secara horizontal \& kawasan menengah ke atas padat secaravertikal.

c. Konektivitas jalan: dari tapak ke Jalan Sultan Iskandar Muda (400 m); Jl. Ciledug Raya (350 $\mathrm{m})$; dan Jl. Teuku Nyak Arief (300 m). Dengan dua nodes yang kuat (Gandaria City, dan Kantor Kelurahan Kebayoran Lama Utara).

\footnotetext{
${ }^{16}$ Kelurahan Kebayoran Lama Utara. Pemerintah Provinsi DKI Jakarta: Laporan Tahun 2019 Kelurahan Kebayoran Lama Utara. [Jakarta: Kelurahan Kebayoran Lama Utara, 2019), hal. 5.
} 
d. Kesenjangan sosial: terlihat sangat kontras antara kawasan menengah ke bawah dan kawasan menengah ke atas.

e. Tempat perdagangan yang strategis: Pasar Kebayoran Lama (550 m); Gandaria City (650 m); dan Pasar Bata Putih (900 m).

f. RTH sebagian besar digunakan sebagai pemakaman, antara lain: Tanah Kusir $(2 \mathrm{~km})$; dan TPU Grogol Selatan Kebayoran Lama $(1.7 \mathrm{~km})$. Selain itu, terdapat dua RPTRA, yaitu: RPTRA Dwi Chandra Loka $(650 \mathrm{~m})$ dan RPTRA Delman Asri $(1.5 \mathrm{~km}) .{ }^{11}$

g. TOD: stasiun Kebayoran Lama $(600 \mathrm{~m})$ [Tanah Abang - Rangkas Bitung]; halte terminal busway Kebayoran Lama koridor $8(550 \mathrm{~m})$ [Harmoni - Lebak Bulus]; dan halte terminal busway Kebayoran Lama koridor $13(500 \mathrm{~m})$ [Ciledug - Kapten Tendean]

h. Rumah sakit: Poliklinik Umum Medika (190 m); JRC Clinic (700 m); Puskesmas Kelurahan Cipulir II (1 km); Rumah Sakit Muhammadiyah (1.2 km); RSUD Kebayoran Lama (1.5 km).

\section{Analisis Tapak}

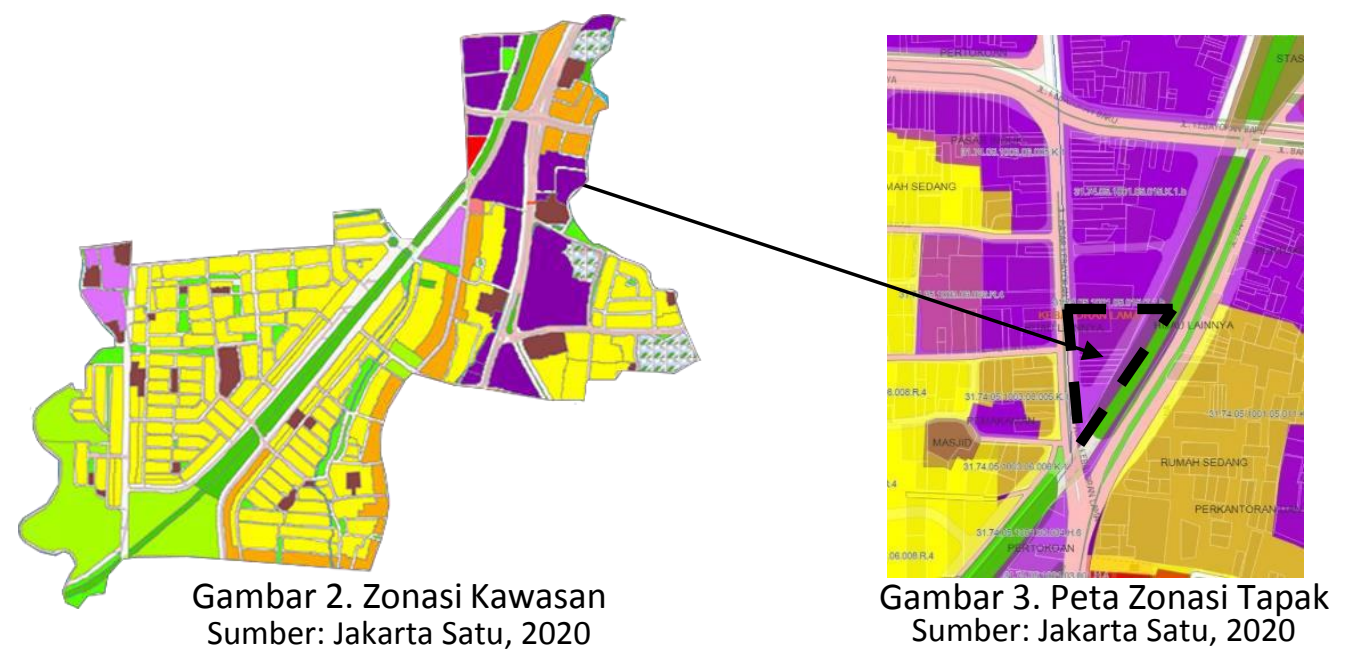

Lokasi tapak berada di Jalan Raya Kebayoran Lama, Kebayoran Lama Utara, Kebayoran Lama, Jakarta Selatan, DKI Jakarta, 12240. Tapak berada di lokasi yang strategis karena berada di zona perdagangan dan jasa, serta permukiman warga. Tapak berada di kawasan menengah ke bawah dengan sekitarnya kawasan menengah ke atas. Selain itu, tapak mud dijangkau karena didekat stasiun Kebayoran dan halte terminal busway Kebayoran Lama koridor 8 dan koridor 13. Tapak yang dipilih berbatasan langsung dengan:

- Utara : Ruko yang berjualan alat dapur elektronik

- Selatan : Rel Kereta api, Jl. Ciputat Raya

- Barat : Jl. Raya Kebayoran Lama, Ruko

- Timur : Rel kereta api, Jl. Baru, Ruko

Peraturan Zonasi Tapak

KDB : $60 \%$

$\mathrm{KLB}: 2,4$

$\mathrm{KB}: 4$

$\mathrm{KDH}: 35 \%$

KTB : $50 \%$

Tipe : D

TPZ : Pusat Kegiatan Tersier Zonasi: Perdagangan dan Jasa 


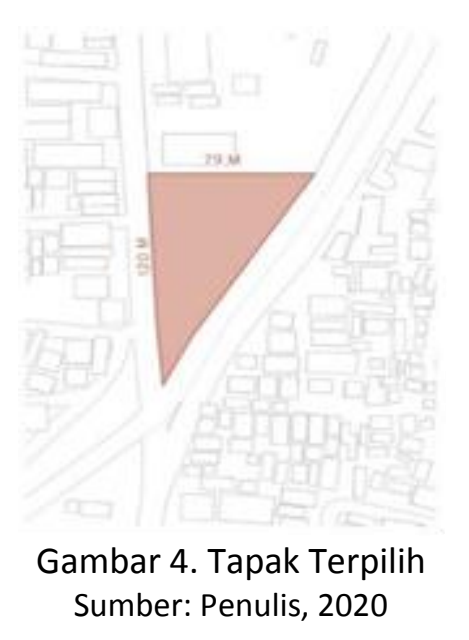

\section{Konsep Perancangan}

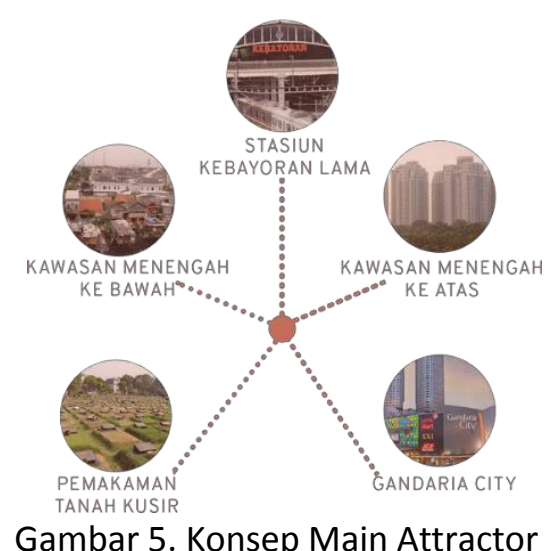

Gambar 5. Konsep Main Attractor Sumber: Penulis, 2020

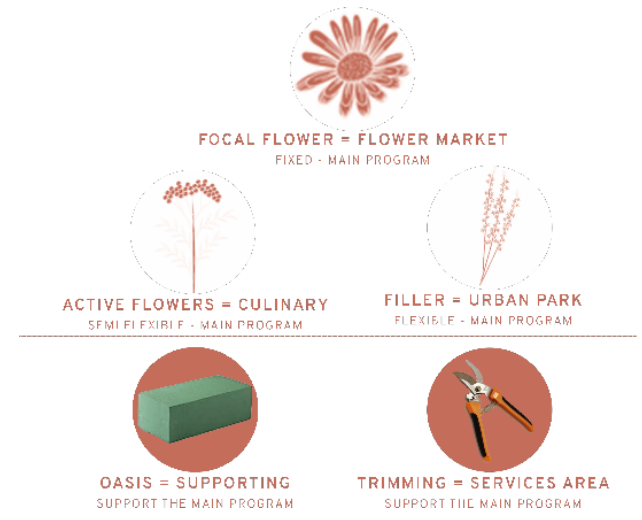

Gambar 6: Konsep Analogi Buket Bunga Sumber: Penulis, 2020

Dalam menjawab permasalahan yang dihadapi, perancangan ini menggunakan tema "urban park" untuk mencirikan konsep kawasan hijau yang alami (nature). Hal ini untuk mencapai RTH minimal kota yang masih sangat jauh. Proyek ini ingin menjadi "Main Attractor" dimana menghubungkan stasiun Kebayoran Lama, kawasan menengah ke atas, Gandaria City Mall, pemakaman Tanah Kusir, dan kawasan menengah ke bawah yang mencerminkan kawasan Kebayoran Lama Utara. Konsep yang dipilih untuk membentuk proyek ini menggunakan analogi sebuah buket bunga yang melambangkan keberagaman dari isu yang dihadapi kawasan ini. Dimana terdapat 3 main program yaitu: terdapat focal flower (bunga inti) - pasar bunga (flower market), active flowers (bunga pendukung) - kuliner, dan filler (pengisi bunga) taman kota (urban park). Tetapi, diperlukan oasis (penyokong bunga) - supporting program, dan trimming (perawatan bunga) - area servis. Untuk mencapai tujuan ini, maka dari itu menggunakan tiga metode dalam pembentukannya, yakni: leveling (terasering), secatered (dipisahkan), dan asymmetrical (tidak simetris) sehingga mencerminkan bentuk yang bunga yang organik.

\section{Pembentukan Massing Type}

Proses pembuatan gubahan massanya: pertama dengan membuat grid persegi berukuran $8 \times 8$ $m$, agar konteks dengan lingkungan sekitarnya (baik dari segi tipologi maupun kegiatan masyarakatnya). Kedua membuat sirkulasi jalan yang organik dengan aksis yang dipilih sehingga mudah dijangkau oleh masyarakat. Ketiga gubahan massa dinaikan untuk memaksimalkan view dari berbagai arah. Keempat massa dibuat terasering dan void untuk mendapatkan pencahayaan dan sirkulasi udara alami yang baik untuk kesehatan. Terakhir 
menambahkan penghubung massa seperti jembatan, tangga, dan urban park untuk meningkatkan penghijauan daerah setempat.
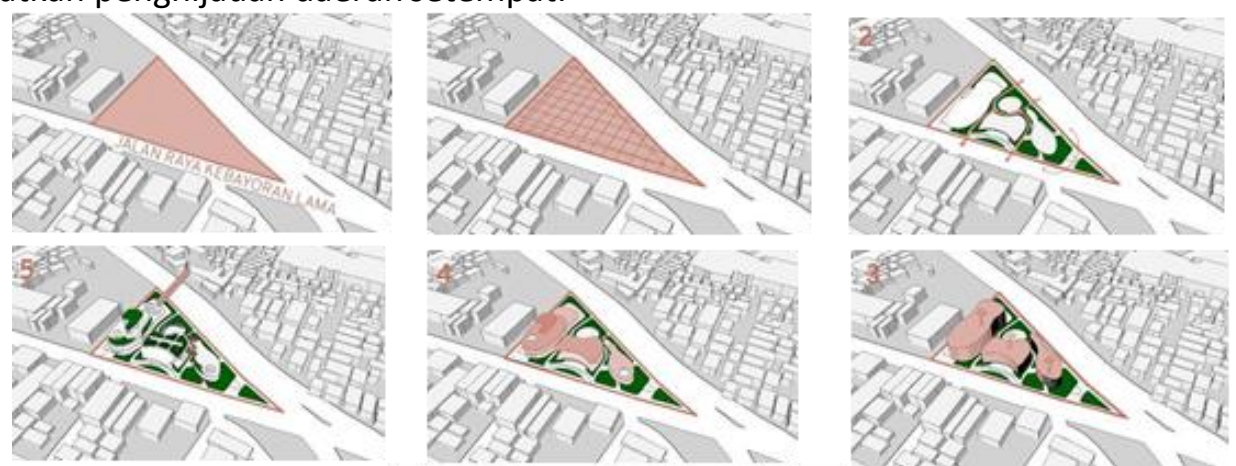

Gambar 7. Proses Perubahan Gubahan Massa

Sumber: Penulis, 2020

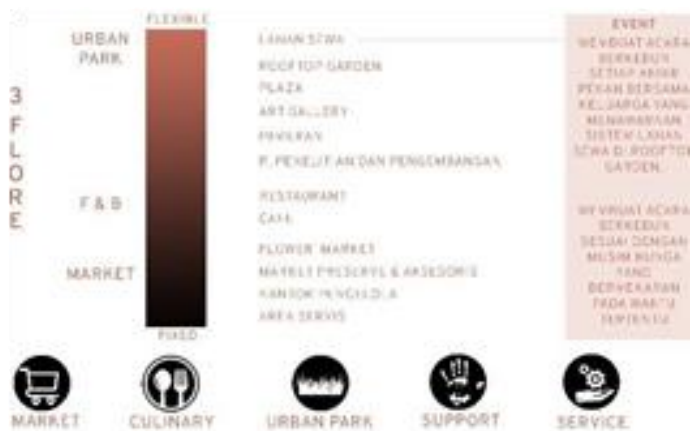

Gambar 8. Program Perancangan

Sumber: Penulis, 2020

\section{Pembentukan Unit Type}

Setelah membuat gubahan massa yang sudah sesuai dengan konsep dan tema yang diambil, maka merangkai unit type yang organik. Hal ini diterapkan dalam elemen arsitektur (dinding, kolom, lantai, atap, dll) sampai dengan furniture yang dipilih agar tetap konteks dan diterapkan pada program terpilih (pasar bunga, kuliner, maupun taman). Dalam pembentukan program, pasar sebagai fixed main program, kuliner sebagai semi flexible main program dan urban park sebagai flexible main program. Dimana terdapat event jumalnongjang dengan sistem lahan sewa yang dilakukan setiap akhir pekan yang dapat dilakukan bersama keluarga ataupun teman di rooftop garden, serta membuat acara berkebun sesuai dengan musim bunga yang bermekaran pada waktu tertentu.

Tabel 1. Program Ruang

\begin{tabular}{|c|c|c|}
\hline Fasilitas & Ruang & $\begin{array}{c}\text { Luasan } \\
\left(\mathbf{m}^{\mathbf{2}}\right)\end{array}$ \\
\hline Pasar Bunga & Pasar Bunga Basah, Pasar Bunga Kering dan Aksesoris & 1020 \\
\hline Kuliner & Restaurant, Cafe & 340 \\
\hline Urban Park & Taman, Gudang & 1706.5 \\
\hline $\begin{array}{c}\text { Penelitian dan } \\
\text { Pengembangan }\end{array}$ & Penelitian dan Pengembangan, Meeting Room, Gudang & 270 \\
\hline $\begin{array}{c}\text { Communal } \\
\text { Space }\end{array}$ & $\begin{array}{c}\text { Learn and Play, Plaza, Outdoor Exhibition, Semioutdoor } \\
\text { Exhibition, Art Gallery }\end{array}$ & 578 \\
\hline Area Servis & Ruang Pengelola, Lobby, Ruang Servis & 2033 \\
\hline \multicolumn{2}{|c|}{ Total } & 5947.5 \\
\hline
\end{tabular}

Sumber: Penulis, 2020 
Program utama yang diusulkan untuk proyek ini, sebagai berikut:

a. Pasar bunga: dipilih karena didaerah sekitar Grogol Selatan yang rata-rata merupakan mayarakat menengah ke atas menyukai bercocok tanam. Menurut Data Jakarta, masyarakat rela mengeluarkan uang untuk non-makanan. Hal ini terlihat, di sekitar apartement mewah terdapat banyak penjual tanaman dipinggir jalan.

b. Kuliner: dipilih karena disekitar kawasan belum terdapat area khusus kuliner. Di daerah setempat hanya banyak terdapat pedagang kaki lima yang menganggu jalan lalu lintas sehingga dapat menyebabkan kemacetan.

c. Urban park: untuk mewujudkan dan menawarkan pengalaman berada di taman bunga ditengah kota. Masyarakat di kawasan Kebayoran Lama Utara, tidak memiliki tempat wisata selain mall. Jika, mereka ingin bermain terdapat RPTRA tetapi hanya dua dan tidak cukup untuk menampung satu kelurahan. Selain itu, proyek ini ingin turut menyumbang RTH minimal kota yang masih sangat jauh dari target.

Dalam mewujudkan program utama, harus dilengkapi dengan program pendukung untuk menunjang kegiatan dan aktivitas dari program utama. Oleh karena itu, menambahkan program pendukung, sebagai berikut:

a. Penelitian dan pengembangan: untuk mendukung keberlangsungan tanaman yang ditanam di taman, sehingga dapat menghadirkan berbagai jenis varian bunga.

b. Learn and play: ditujukan kepada anak-anak yang disekitar kawasan tersebut tidak memiliki tempat bermain dan belajar yang layak dengan mengambil konsep ruang tanpa sekat.

c. Plaza: tempat menghubungkan semua kegiatan dan aktivitas yang ada. Plaza bisa menjadi tempat berkumpul, mengadakan event seperti: workshop, tempat temu komunitas sepeda, tempat berolahraga, pentas seni dan tari, dll.

d. Outdoor exhibition: tempat penerima pengunjung yang melewati jembatan penyebrangan sehingga dapat menarik perhatian orang yang berkunjung, meskipun hanya melewatinya.

e. Semioutdoor exhibition: tempat pameran semipublik untuk beberapa jenis tanaman yang tidak boleh terkena sinar matahari langsung.

f. Art gallery diletakkan di tempat komunal sehingga ketika orang melewatinya dapat melihat pameran atau event yang sedang berlangsung.

\section{Zoning dan Sirkulasi}

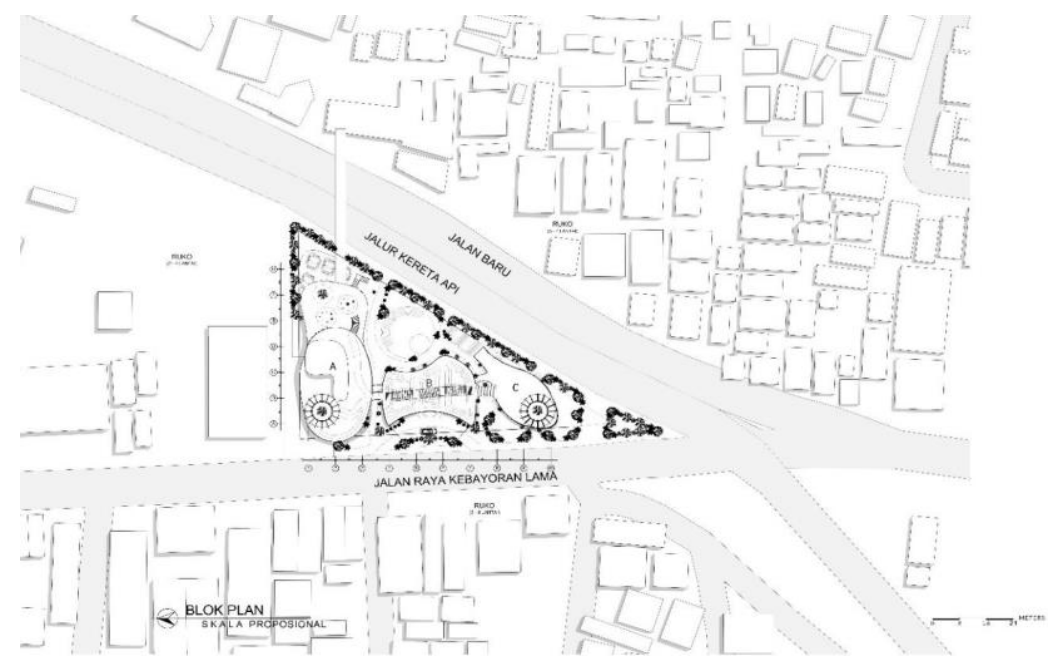

Gambar 9. Block Plan

Sumber: Penulis, 2020 
3 Flore Kebayoran Lama Utara menghadap ke Barat bangunan dengan Jalan Raya Kebayoran Lama sebagai jalan utamanya. Bangunan ini terdapat tiga massa bangunan. Pada massa bangunan A terdapat pasar bunga (flower market), art gallery, outdoor exhibition, research area, rooftop garden, core bangunan, dan area servis (services area). Massa bangunan B terdapat lobby utama (main entrance), pasar bunga kering dan aksesoris (flower preserved and accessories market), ruang pengelola (management room), semi-outdoor exhibition, dan rooftop garden. Massa bangunan C terdapat kuliner (culinary area), dan tempat bermain dan belajar (Learn and Play).

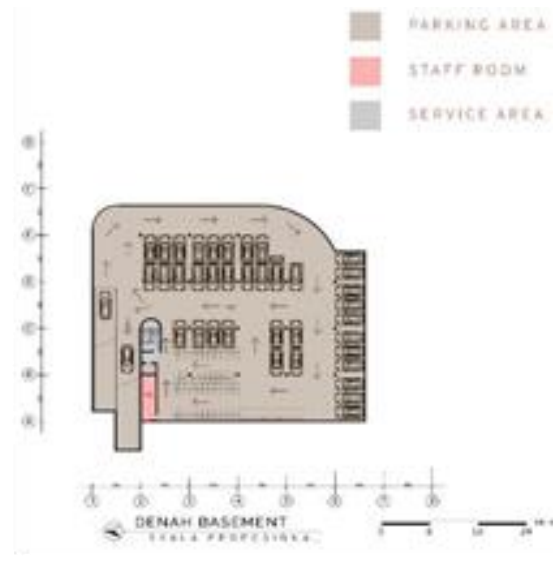

Gambar 10. Denah Basement Sumber: Penulis, 2020

3 Flore Kebayoran Lama Utara menghadap ke Barat bangunan dengan Jalan Raya Kebayoran Lama sebagai jalan utamanya. Bangunan ini terdapat tiga massa bangunan. Pada massa bangunan A terdapat pasar bunga (flower market), art gallery, outdoor exhibition, research area, rooftop garden, core bangunan, dan area servis (services area). Massa bangunan B terdapat lobby utama (main entrance), pasar bunga kering dan aksesoris (flower preserved and accessories market), ruang pengelola (management room), semi-outdoor exhibition, dan rooftop garden. Massa bangunan $\mathrm{C}$ terdapat kuliner (culinary area), dan tempat bermain dan belajar (Learn and Play). Basement terdapat 36 tempat parkir mobil dan 42 parkir motor. Hal ini tidak sebanyak parkiran biasa untuk mengurangi penggunaan kendaraan pribadi dan lebih menggunakan kendaraan umum. Selain itu, tersedia ruang tunggu dan ruang staff.

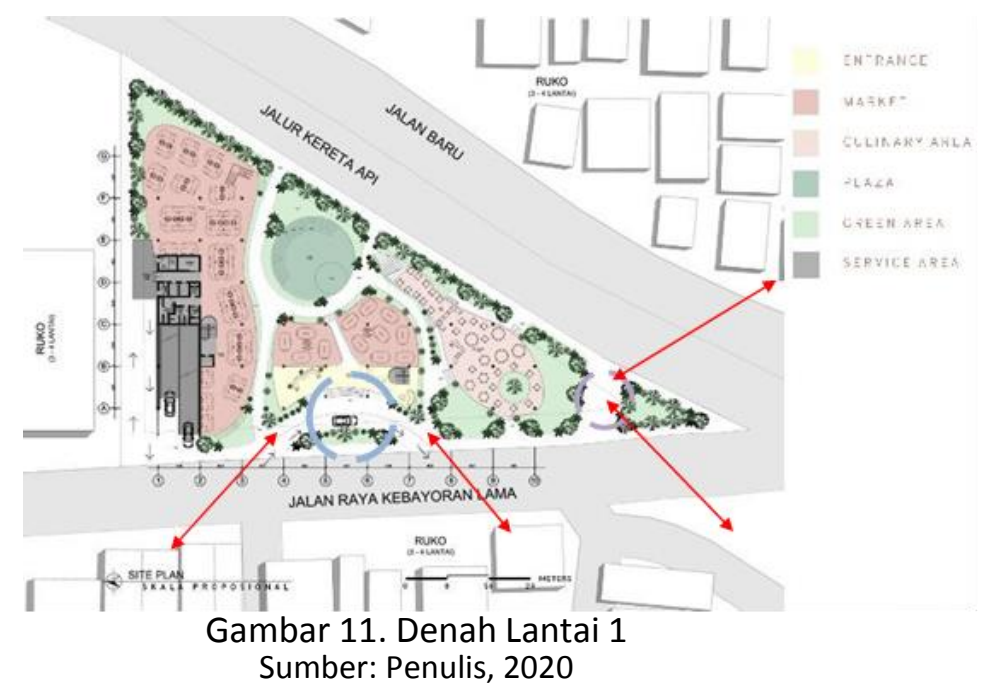


Pada lantai 1 terdapat main entrance (drop-off mobil) dan side entrance (untuk drop off ojek online) untuk menghindar kemacetan. Ketika masuk melalui main entrance [biru], akan masuk ke area lobby utama, dan pasar bunga kering \& aksesoris (flower preserved \& accessories market). Jika masuk melalui side entrance [ungu] akan masuk ke area kuliner (culinary area). Selain itu, pasar bunga (flower market) yang dekat dengan area core bangunan, services area, dan loading dock. Plaza sebagai penghubung tiga massa bangunan. Lantai 2 massa A terdapat outdoor exhibition, art gallery, research area, dan core bangunan. Pada massa B terdapat semioutdoor exhibition, management room, dan art gallery. Pada massa $\mathrm{C}$ terdapat learn and play. Semua massa dihubungkan dengan jembatan. Pada lantai 3 terlihat seperti sebuah massa karena digunakan sebagai penghijauan (rooftop garden) dengan dibuat secara terasering. Semua massa dihubungkan dengan tangga dan jembatan. Pada massa $B$, dinaikkan $1.60 \mathrm{~m}$ dari lantai sehingga dapat melihat pemandangan di sekitarnya. Di area bawah terasering yang dinaikkan dimanfaatkan sebagai tempat penyimpanan. Hal ini untuk memaksimalkan tempat yang ada.

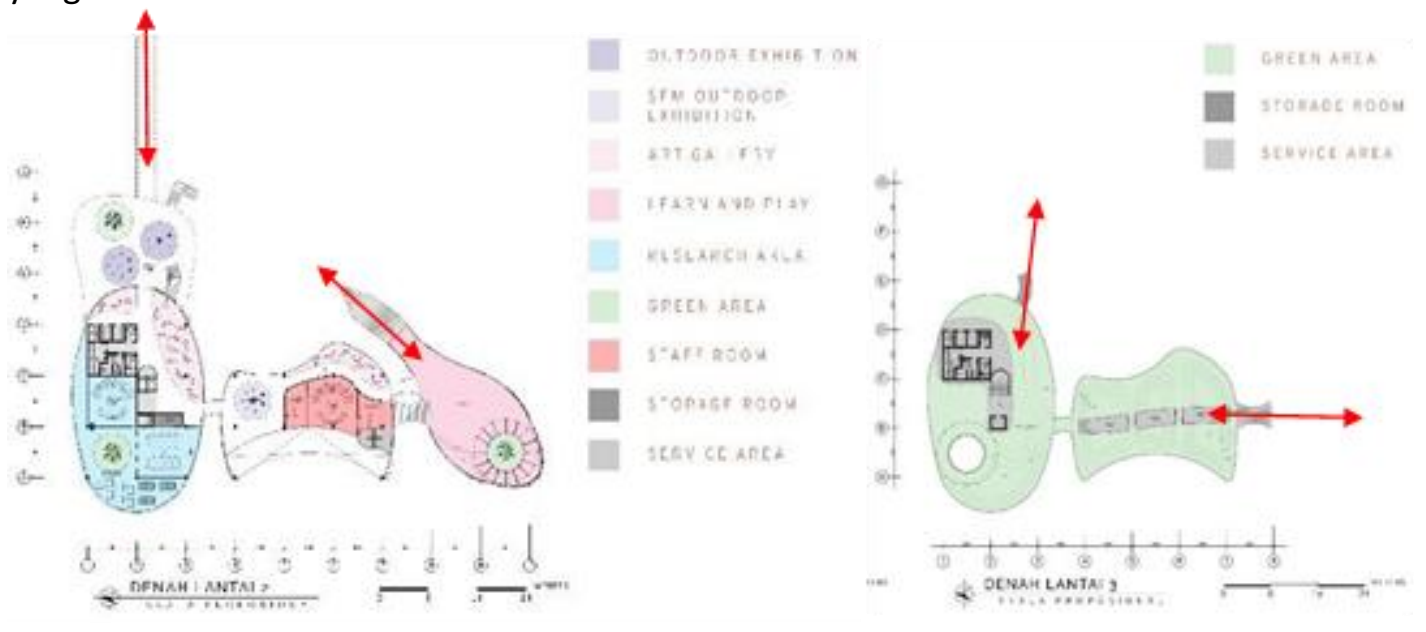

Gambar 12. Denah Lantai 2 dan Gambar 13. Denah Lantai 3 Sumber: Penulis, 2020
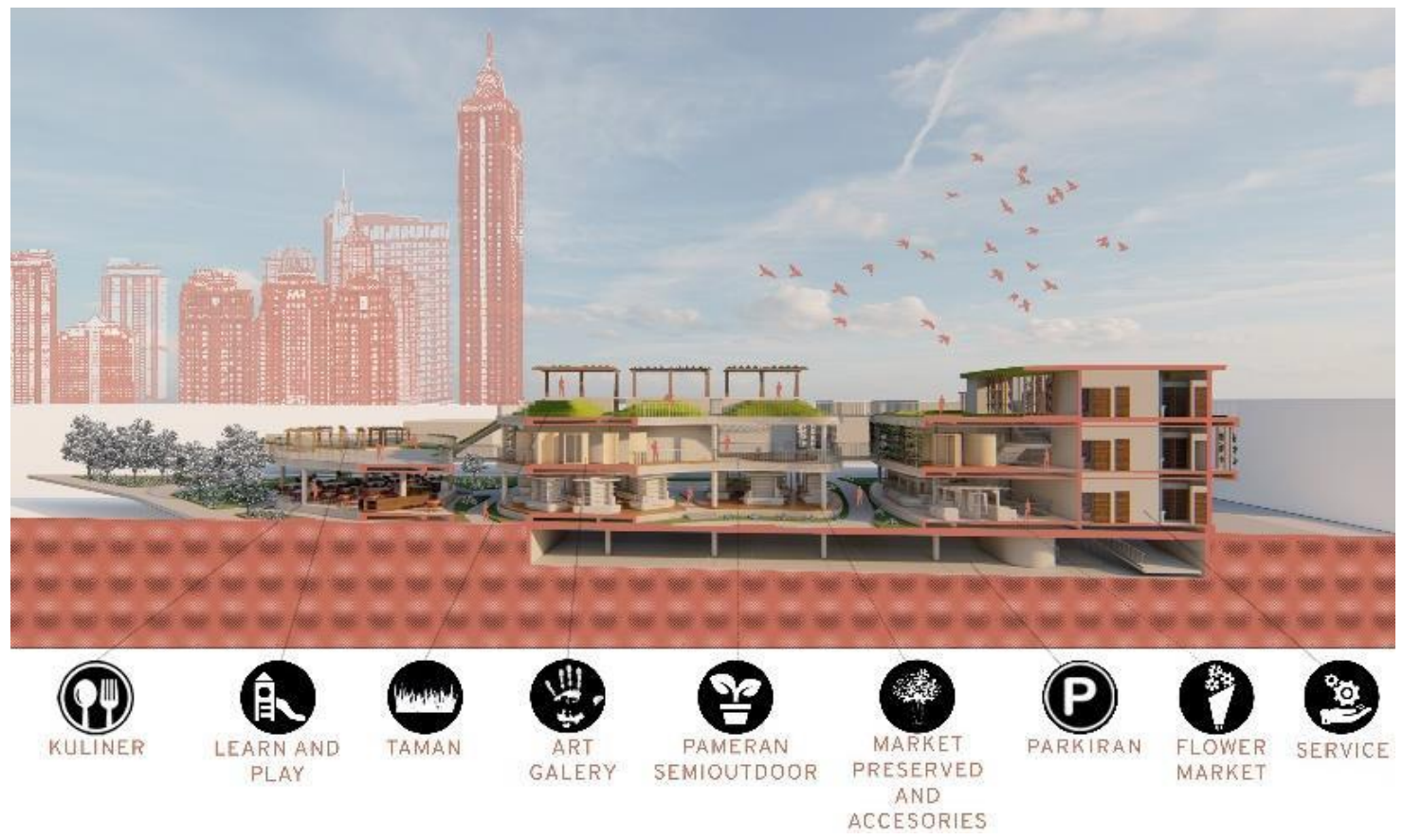

Gambar 14. Potongan Perspektif

Sumber: Penulis, 2020

Secara vertikal bangunan memiliki zoning massa yang linear. Pada lantai dasar 
merupakan area publik dan area rembesan dari second place ke first place. Pada lantai 2 terdapat jembatan penyebrangan orang sehingga menjadikan area tersebut komunal (art gallery, semioutdoor exhibition, outdoor exhibition) dan orang akan tertarik berkunjung ke bangunan ini. Pada lantai 3 digunakan sebagai rooftop garden publik dan tetap terhubung sampai ke lantai dasar. Hal ini sebagai bentuk penunjang RTH minimal kota.

\section{Struktur dan Material}

Struktur bangunan secara garis besar menggunakan beton bertulang, dengan grid $8 \times 8 \mathrm{~m}$ yang berbentuk persegi sehingga konteks dengan lingkungan sekitarnya. Struktur kolom beton berukuran $50 \times 50 \mathrm{~cm}$ dan balok beton bertulang berukuran $40 \times 20 \mathrm{~cm}$. Dinding bangunan menggunakan material beton expose dengan ketebalan $15 \mathrm{~cm}$ dan dinding core dengan ketebalan $20 \mathrm{~cm}$. Lantai bangunan menggunakan struktur beton bertulang dengan ketebalan $12 \mathrm{~cm}$. Lantai pasar menggunakan material keramik. Lantai art gallery, outdoor exhibition, semi-outdoor exhibition menggunakan material parket. Atap dijadikan rooftop garden dengan ketebalan lantai $40 \mathrm{~cm}$. Bangunan ini menggunakan material dengan warna yang netral. Dalam mewujudkan green architecture, fasad bangunan diberikan kisi-kisi kayu berdiameter $10 \mathrm{~cm}$ diberikan tanaman gantung (ivy) atau bunga kertas (bougenville) untuk mempercantik. Pengudaraan dan pencahayaan bangunan ini cenderung alami, hanya menggunakan pengudaraan dan pencahayaan buatan di ruangan lebih privat seperti ruang pengelola.

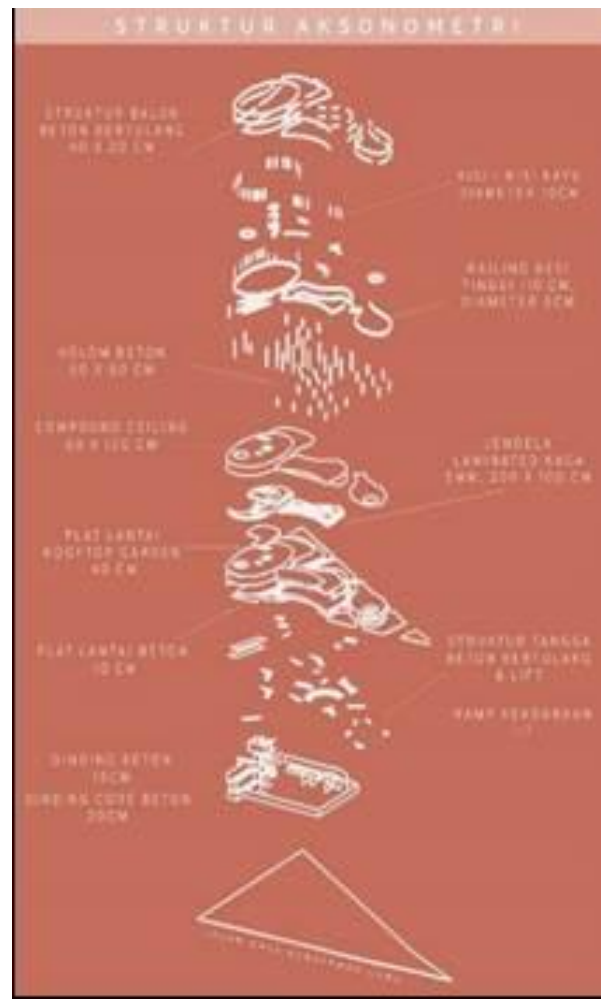

Gambar 15. Struktur Aksonometri Sumber: Penulis, 2020 


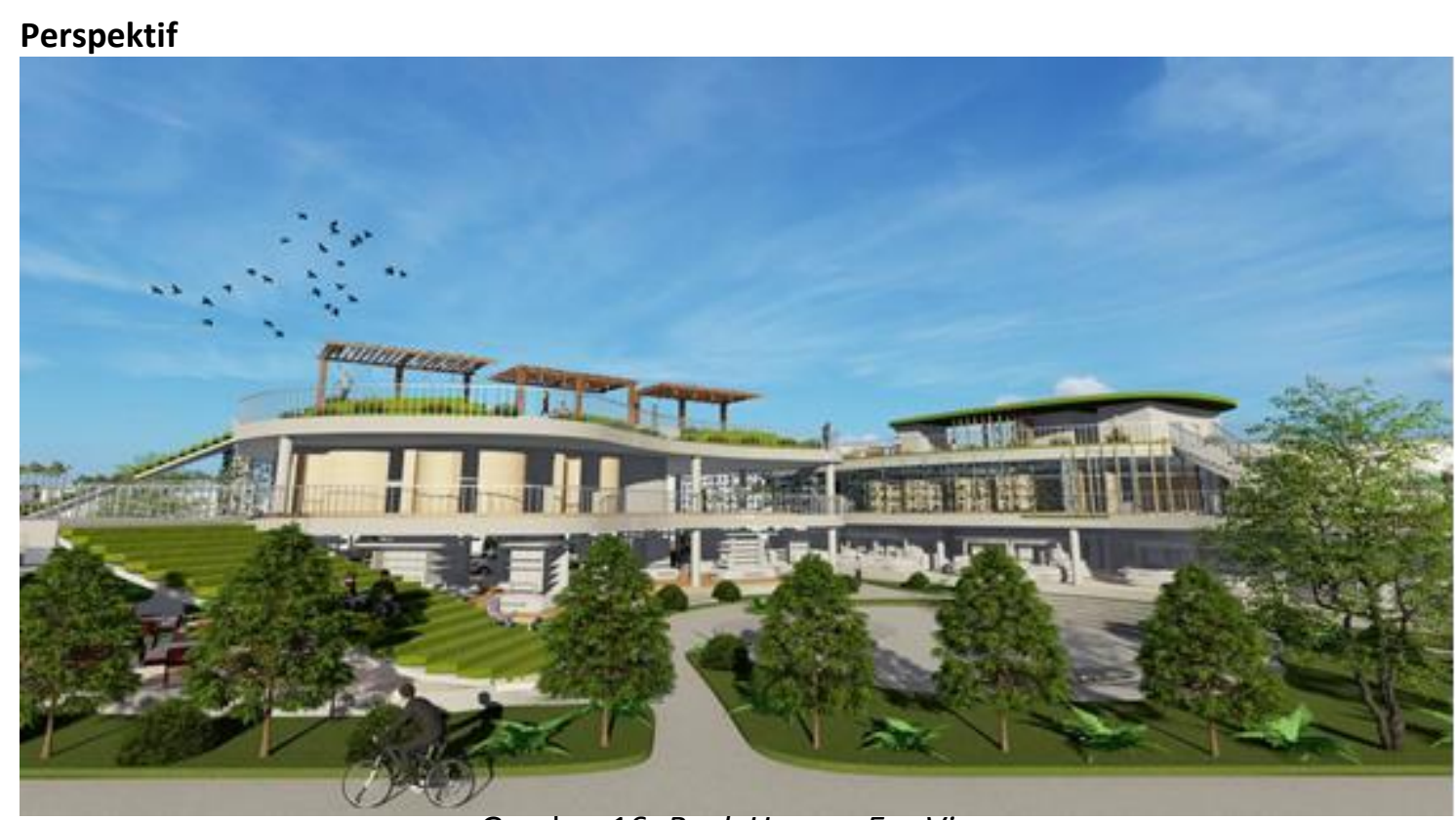

Gambar 16. Back Human Eye View

Sumber: Penulis, 2020

Bangunan ini didesain ingin menjadi "main attractor". Tetapi, tetap dibuat secara sederhana, nature, dan konteks dengan lingkungan sekitarnya sehingga tetap mencerminkan kawasan Kebayoran Lama Utara. Flower market dibuat dengan bentuk stand yang unik dan terdapat tempat penyimpanan (chiller) untuk menyimpan bunga agar tetap dalam keadaan segar. Culinary area terdapat void yang berisi pohon, agar ketika pengunjung makan atau minum ditawarkan sebuah pengalaman dengan alam. Rooftop garden dibuat secara terasering dan menggunakan pergola yang ditambahkan dengan tanaman gantung (ivy) dan boungenville sebagai peneduh.

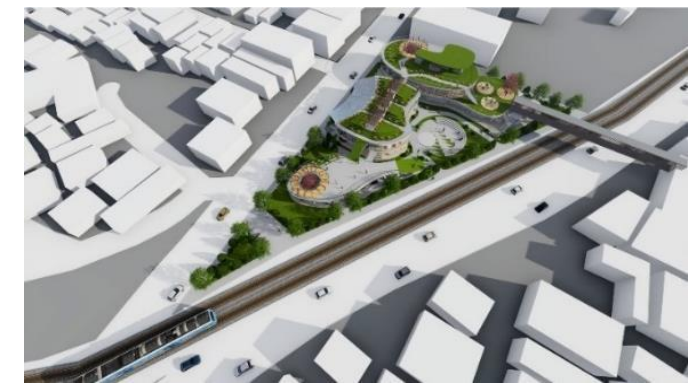

Gambar 17. Back Bird Eye View Sumber: Penulis, 2020

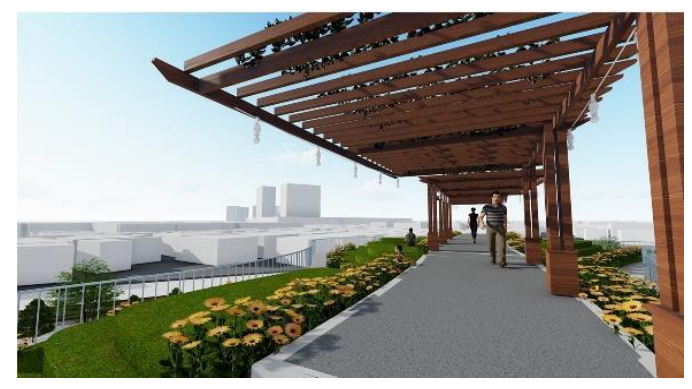

Gambar 19. Rooftop Garden Sumber: Penulis, 2020

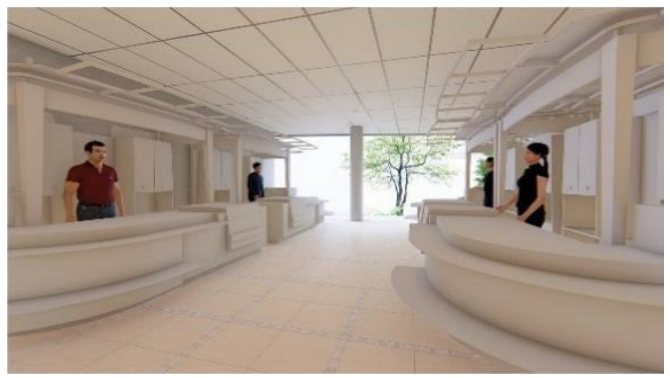

Gambar 18. Flower Market Sumber: Penulis, 2020

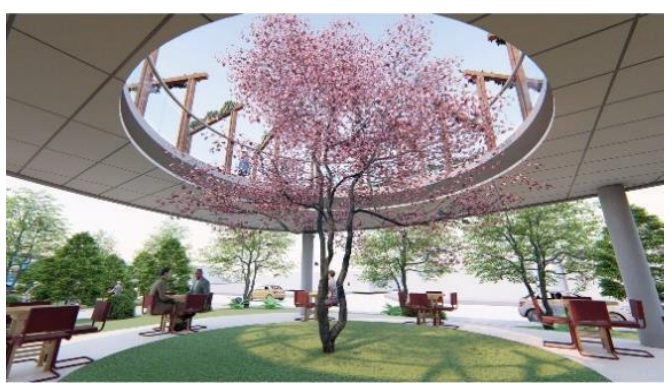

Gambar 20. Culinary Area Sumber: Penulis, 2020 


\section{KESIMPULAN DAN SARAN}

Kesimpulan

Proyek third place ini diharapkan dapat menjadi ruang publik informal dan penunjang keberadaan RTH kota yang masih jauh dari target. 3 Flore merupakan sebuah ide perancangan third place di Kebayoran Lama Utara, Kebayoran Lama, Jakarta Selatan. Dengan melakukan eksplorasi program dengan merancang sebuah pasar bunga yang dikombinasikan dengan tempat kuliner dan taman kota. Perpaduan program yang dihasilkan ingin membuktikan jika proyek ini terbentuk dari sebuah kawasan dan berguna bagi masyarakat sekitarnya.

\section{Saran}

Akhir kata, penulis berharap bahwa dengan adanya perancangan ini arsitektur di masa mendatang dalam merancang third place harus menjawab permiabilitas dan keterbukaan agar mudah dicapai masyarakat. Dalam merancang suatu proyek harus memperhatikan setiap elemen perkotaan, seperti: ruang publik, RTH, dsb. Selain itu, harus mengetahui potensi kawasan untuk menghadirkan program yang tepat yang dapat mencerminkan suatu kawasan.

\section{REFERENSI}

Biblus. (n.d.). (2020). Urban Park Design and Planning: Main Types and Features of Green Areas Together with a 3D Model Ready to Use. biblus.accasoftware.com. Diambil 15 Februari 2020, dari http://biblus.accasoftware.com/en/urban-park-design-concepts-and-keyelements/

Budiharjo, E. dan Sujarto, D. (1999). Kota Berkelanjutan (Sustainable City). Alumni.

CNN Indonesia. (2019). Target Masih Jauh DKI Ingin Swasta Sumbang 10 Persen RTH. CNN Indonesia. https://www.cnnindonesia.com/nasional/20191017195256-20-440515/targetmasih-jauh-dki-ingin-swasta-sumbang-10-persen-rth

GC, Virginia. (2014). Principles and Elements of Design (hal. 1-2). http://www.gcvirginia.org/userfiles/file/principleselements.pdf

Gischa, S. (2020). Pasar: Pengertian, Fungsi, Ciri-ciri dan Jenisnya. Kompas.com. https://www.kompas.com/skola/read/2020/01/27/120000769/pasar-pengertian-fungsiciri-ciri-dan-jenisnya?page=all\#: :text=Pengertian pasar,orang-orang dengan imbalan uang.

Iftitach. (2013). Public Space. Scribd. https://id.scribd.com/doc/172700187/Public-Space

Informasi, K. (2019). Pengertian Kuliner. https://www.kanalinfo.web.id/pengertian-kuliner

Jakarta Open Data. (2018). Data Rekap Luas Ruang Terbuka Hijau Per Kotamadya di DKI Jakarta.

https://data.jakarta.go.id/dataset/rekapluasruangterbukahijauperkotamadyadidkijakarta

Kelurahan Kebayoran Lama Utara. (2019). Pemerintah Provinsi DKI Jakarta: Laporan Tahun 2019 Kelurahan Kebayoran Lama Utara.

Larice, M. dan Macdonald, E. (2007). The Urban Design Reader. In Routledge (2nd ed.).

Library Binus. (2017). Bab II: Landasan Teori. http://library.binus.ac.id/eColls/eThesisdoc/Bab2/RS1_2017_1_326_Bab2.pdf

London Assembly. (2011). Public Life in Private Hands: Managing London's Public Space (hal. 47). Greater London Authority.

Oldenburg, R. (1999). The Great Good Place: Cafes, Coffee Shops, Bookstores, Bars, Hair Salons, and Other Hangouts at The Heart of Community (Marlowe (Ed.); 1999 ed.). Da Capo Press.

Presiden Republik Indonesia. (2007). UU RI no. 26 tahun 2007. kemenkeu.go.id. https://jdih.kemenkeu.go.id/fullText/2007/26TAHUN2007UU.HTM

Syasya. (2019). Julmanongjang Hobi Orang Kota di Korea. Kompasiana.com. https://www.kompasiana.com/lakeisha/5dad5050c0cfa1022f731652/jumalnongjang-hobiorang-kota-di-korea

Wikipedia. (2019). Bunga. Wikipedia. https://id.wikipedia.org/wiki/Bunga 